JURNAL INKLUSIF : Jurnal Pengkajian Penelitian Ekonomi dan Hukum Islam Vol: 4 No: 1 June 2019 Published by Pascasarjana IAIN Syekh Nurjati Cirebon, Indonesia. p-ISSN: 2303-2669, e-ISSN: 2548-9631

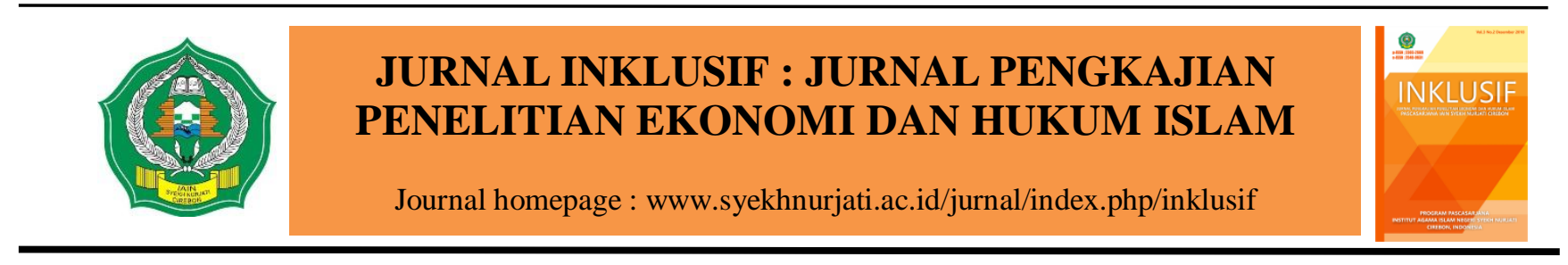

\title{
MODEL PENGEMBANGAN UKM INDUSTRI EKONOMI KREATIF DI KOTA CIREBON DALAM PRESFEKTIF EKONOMI ISLAM

\author{
Heru Kurniawan $^{1}$
} \\ Email: Khoirullkurniawan91@gmail.com
}

\section{Artikel info:}

Received: 20

December 2018

Revised form: 3

January 2019

Accepted: 7

February 2019

Available online: 17 Mei Tahun 2019

\section{ABSTRACT}

The creative economy is a concept in a new economics era which considers information and creativity by relying on ideas and thoughts from human resources as the main production factor. In progress, the creative economy, especially in West Java uses the model of Quadruple helix where government, people in business, academicians, and communities become the main actor from the model. In Cirebon, there are some problems faced by creative economic actors as follows lack of competent human resources, lack of capital, and lack of marketing access.

This study got the result as an action conducted by the Cirebon authorities in supporting the progress of the creative economy as follows doing entrepreneurship training, UKM go online training, product packaging training, and taxation training. In the capital sector, the actions can be financing socialization, program socialization from the Ministry, and checking to ensure the reality of UKM. In the marketing sector, the effects can be the improvement of partnership for small-medium enterprise with private segments, the implementation of UKM product promotion, the cooperation with a market place online, the collaboration with supermarket and mini market and the supplying of Web UKM Keywords: Creative Economy, Model, Islami

\begin{abstract}
ABSTRAK
Ekonomi kreatif adalah sebuah konsep di era ekonomi baru yang mengutamakan informasi dan kreativitas dengan mengandalkan ide dan pengetahuan dari sumber daya manusia sebagai faktor produksi yang utama. Dalam pengembanganya ekonomi kreatif khususnya di Jawa Barat menggunakan model Quardple helix dimana peran pemerintah, pengusaha, akademik dan komunitas menjadi aktor utama dari model tersebut. Di kota cirebon terdapat beberapa kendala yang dihadapi oleh para pelaku ekonomi kreatif diantaranya adalah sumber daya manusia yang kurang kompeten, kurangnya modal, serta akses pemasaran masih lokal.

Hasil dari penelitian ini berupa tindakan yang dilakukan oleh pemerintah kota cirebon dalam mendukung pengembangan ekonomi kreatif seperti, mengadakan kegiatan Pelatihan kewirausahaan, Pelatihan UKM go Online, Pelatihan pengemasan produk dan Pelatihan perpajakan. Dalam bidang permodalan hal yang dilakukan berupa kegiatan Sosialisasi permodalan, Sosialisasi program dari kementrian serta Pengecekan untuk
\end{abstract}

\footnotetext{
${ }^{1}$ Mahasiswa Ekonomi Syari'ah Pascasarjana IAIN Syekh Nurjati Cirebon.
} 
memastikan kebenaran UKM. Dalam bidang pemasaran hal yang dilakukan berupa Peningkatan kemitraan bagi usaha kecil menengah dengan pihak swasta, Penyelenggaraan promosi produk UKM, Kerjasama dengan market place online, Kerjasama dengan supermarket dan mini market serta Penyediaan Web UKM.

Kata kunci : Ekonomi Kreatif, Model, Islam

\section{PENDAHULUAN}

Pengembangan model ekonomi kreatif di Indonesia khususnya di Jawa Barat menggunkan Model Quadruple Helix dimana terdapat unsur penting dalam pengembangan ekonomi kreatif diantaranya keterlibatan Pemerintah, pengusaha/swasta, akademik serta peran komunitas dan memberi nama model tesebut dengan sebutan Jabar Masagi. Model pengembangan ekonomi kreatif dengan memasukan aktor ke-4 yang juga penting dalam pembangunan ekonomi kreatif di Indonesia yaitu komunitas akan melengkapi aktor akademisi menjadi intelektual, karena dalam ekonomi kreatif banyak sekali tokoh-tokoh kreatif yang lahir dari komunitas dan masyarakat tanpa memiliki latar belakang pendidikan akademis.

Model ekonomi kreatif akan berkembang jika ditopang oleh beberapa pilar diantaranya; Sumber daya pendukung (sumberdaya insani, sumberdaya budaya lokal dan sumberdaya alam). Industri, keseluruhan industri kreatif tersebut haruslah ditopang oleh industri utama seperti halnya pabrik kertas untuk industri percetakan, pabrik kayu untuk kerajinan, industri kain bahan untuk fashion, industri elektronik untuk film dan media informasi dll. Pembiayaan, lembaga pmbiayaan berperan menyalurkan pendanaan kepada para pelaku ekonomi kreatif baik itu berupa pinjaman ataupun permodalan baik menggunaan sistem syariah maupun konvensional. Pemasaran, pemasaran merupakan harapan terbesar dari para pelaku ekonomi kreatif di Jawa Barat dibandingkan dengan keuangan serta tenaga kerja. Teknologi serta infrastruktur, infrastruktur melingkupi kebijakan, inovasi, dukungan, serta lingkungan yang mendukung, serta kemudahan akses internet dan komunikasi.

BEKRAF-BPS, pada tahun 2017 menyebutkan jumlah pengusaha ekonomi kreatif di Kota Cirebon sebesar 16.154 dengan tiga sektor besar ekonomi kreatif diantaranya kuliner dengan 13.273 pelaku usaha, fashion dengan 1.539 pelaku usaha dan kriya sebesar 660 pelaku usaha. ${ }^{2}$ Namun hal ini berbeda dengan jumlah pengusaha akonomi kreatif yang telah terdaftar di Disperindag Kota Cirebon yang pada tahun 2017 merilis jumlah pelaku UKM di Kota Cirebon yang tersebar dilima Kecamatan berjumlah 320 diantaranya adalah; Kec. Kejaksan terdapat 41 pelaku UKM, Kec. Kesambi terdapat 89 pelaku UKM, Kec. Lemah Wungkuk terdapat 46 pelaku UKM, Kec. Pekalipan terdapat 40 pelaku UKM dan Kec. Harjamukti terdapat 104 pelaku UKM.

Pelaku UKM yang tersebar dilima Kecamatan tersebut dapat dikerucutkan kembali berdasarkan kategori pelaku UKM ekonomi kratif menjadi 221 pelaku UKM, pelaku UKM ekonomi kreatif tersebar dibeberapa kecamatan diantaranya; Kec. Harjamukti, terdapat 69

\footnotetext{
${ }^{2}$ Citra Nadia, “Cirebon Kota Pertama Di Gelar Bisma Goes to Get Member,” 2018, www.bekraf.go.id,.
} 
pelaku UKM (3 pelaku di bidang Desian interior, 1 pelaku dibidang disain komunikasi visual, 10 pelaku dibidang fashion, 2 Pelaku di bidang Kriya, 52 pelaku dibidang kuliner dan 1 pelaku dibidang seni pertunjuka). Kec. Kejaksan terdapat 33 Pelaku UKM (1 pelaku dibidang Desain Komunikasi Visual, 5 pelaku dibidang Fashion, 1 pelaku dibidang kriya, 26 pelaku dibidang kuliner). Kec. Kesambi, terdapat 62 pelaku UKM (1 pelaku dibidang aplikasi dan pengembangan permainan, 2 pelaku dibidang komunikasi visual, 6 pelaku dibidang fashion, 3 pelaku dibidang kriya, 48 pelaku dibidang kuliner dan 2 pelaku dibidang senirupa). Kec. LemahWungkuk, terdapat 29 pelaku UKM (1 pelaku dibidang fashion, 2 pelaku dibidang kriya dan 26 pelaku dibidang kuliner). Kec. Pekalipan, terdapat 28 pelaku UKM (2 pelaku dibidang fashion, 3 pelaku dibidang kriya dan 23 pelaku dibidang kuliner).

Data diatas merupakan data yang diambil dari Disperindag Kota Cirebon yang menggambarkan jumlah pelaku UKM sebanyak 221 pelaku usaha yang tergolong pada usaha ekonomi kreatif yang tersebar di wilayah Kota Cirebon, dengan persentase $79 \%$ merupakan sub sektor kuliner, $10,85 \%$ sub sektor fashion, $5 \%$ sub sektor kriya dan sisanya kurang dari $5 \%$ adalah desain interior dan desain visual, seni rupa dan seni pertunjukan (showbiz). ${ }^{3}$

Permasalahan ekonomi kreatif di Kota Cirebon bagi pelaku usahanya sendiri adalah kurangnya regulasi permodalan yang diperoleh oleh pelaku usaha kreatif, harga barang baku yang mahal, sumberdaya tidak memumpuni, akses pemasaran yang masih terbatas dan banyak lainya, sedang permasalahan bagi pemerintah sendiri adalah bagaimana agar anakanak muda asli Kota Cirebon tidak memilih menjadi pekerja dan merantau keluar kota setelah lulus dari Sekolah menengah atas ataupun sekolah tinggi, seperti yang di sampaikan oleh anggawira. ${ }^{4}$

Permodalan yang sulit merupakan permasalah yang paling besar yang dihadapi oleh pelaku ekonomi kreatif, pemodalah dirasa paling sulit hal ini dapat dilihat dari beberapa alasan diantaranya : unbankable UKM tidak memenuhi sarat dalam menerima permodalan dari bank, intangible asset pada umumnya yang dilihat oleh penyedia modal adalah Asset fisik sedangkan aset utama ekonomi kreatif adalah intangible Asset yakni berupa daya cipta dan kreatif), High risk karena sedikitnya Asset yang digunakan maka lembaga permodalan menganggap beresiko besar, unpredictable tidak dapat diprediksi mengenai pendapatan serta kemampuanya dalam mengembalikan modal pinjaman karena resiko yang besar jika kreasinya tidak diminati oleh konsumen, dan cas Low nya yang di anggap belum mampu stabil. $^{5}$

Permasalahan kedua menyangkut Sumber daya manusia yang merupakan kendala bagi para pelaku UKM industri ekonomi kreatif di Kota Cirebon, Ricky Joseph sebagai Wakil Kepala (Bekraft) menuturkan aset utama industri kreatif adalah manusia yang memproduksi gagasan

\footnotetext{
${ }^{3}$ Wartoyo, Pemetaan Ekonomi Kreatif Dalam Upaya Pengembangan Dan Peningkatan Ekonomi Kota Cirebon (Cirebon: IAIN Syekh Nurjati Cirebon, 2017). 31.

${ }^{4}$ Arif, “Dongkrak Ekonomi Kreatif Putra Daerah Ini Inisiasi Gerakan Kemakmuran Cirebon," 2017, http://www.tribunnews.com.

${ }^{5}$ Mari Lela Pangestu, Kebangkitan Ekonomi Kreatif (Jakarta: Retas Bekraf, 2016). 36.
} 
atau ide kreatif yang mampu mngembangankan industri kreatif. ${ }^{6}$ Sumber daya manusia baik secara kualitas dan kuantitas menjadi kendala utama pengembangan industri kreatif, hal ini dikarenakan sebagian besar SDM industri kreatif belajar secara otodidak sehingga kualitasnya belum cukup merata, kendala kualitas SDM tersebut menjadi perhatian bersama karena kontribusinya terhadap perekonomian Nasional cukup signifikan. Sumber Daya Manusia (SDM) yang kurang mumpuni juga menjadi kendala untuk bersaing di pasar domestik. ${ }^{7}$

Sumber daya manusia merupakan salah satu faktor yang sangat penting dalam suatu perusahaan. Sumber daya manusia merupakan salah satu faktor kunci dalam persaingan global yakni bagaimana menciptakan sumber daya manusia yang berkualitas dan memiliki keterampilan serta berdaya saing tinggi dalam persaingan global yang selama ini kita abaikan. Selain itu, dalam ekonomi kreatif knowladge sumber daya manusia memiliki peran yang dominan, karena pengetahuan adalah bentuk dasar dari kapital, upaya pengembangan teknologi baru, sehingga dapat menciptakan technical platform untuk inovasi, dapat meningkatkan nilai pengembalian investasi yang tidak dapat dilakukan bila hanya menambah tenaga kerja dan sumber daya material. ${ }^{8}$

Permasalahan terbesar ketiga yang dihadapi oleh pelaku industri ekonomi kreatif di kota Cirebon adalah akses pemasaran, para pelaku industri kreatif belum memiliki akses yang luas ke pasar Internasional. Keterbatasan akses ini disebabkan volume produksi yang belum mencapai batas minimum ketentuan impor, selain itu target pasar yang jelas dan berorientasi domestik terbatas produksi. Sehingga pengembangan produk kreatif masih terbatas pada hal yang umumnya sudah beredar di pasar dan penjualannya masih menggunakan cara konvensional. ${ }^{9}$ Hal tersebut merupakan salah satu kendala yang menyebabkan kurang berkembangnya jangkauan pemasaran industri kreatif di Kota Cirebon, kita ketahui bersama bahwa semakin luas wilayah pemasaran suatu produk kreatif mencerminkan semakin banyaknya permintaan terhadap produk tersebut maka semakin banyak pula jumlah barang dan jasa yang akan dihasilkan. Adapun permasalahan dalam penelitian ini adalah: Bagaimana usaha pemerintah kota Cirebon dalam mengatasi masalah permodalan, bagaimana usaha pemerintah Kota Cirebon dalam meningkatkan kompetensi Sumber Daya Manusia, bagaimana usaha pemerintah Kota Cirebon dalam menanggulangi masalah pemasaran, bagaimana tinjauan ekonomi islam terhadap model pengembangan ekonomi kreatif di Kota Cirebon.

\section{METODE PENELITIAN}

Penelitian ini menggunakan metode kualitatif analisi deskriktif dimana dalam peneliti ini menekankan sifat realitas yang dibangun secara sosial. Penelitian tersebut menekankan

\footnotetext{
${ }^{6}$ Jane Aprilyani, “SDM Topang Pertumbuhan Ekonomi Kreatif," 2018, https://www.kontan.go.id.

7 Wawan, "SDM Jadi Kendala Utama Industri Kreatif," 2012, www.Kompas.com.

${ }^{8}$ Ayu Lucy Larassaty, "Kontribusi Sumberdaya Manusia Di Bidang Industri Kreatif” (Bandung, 2016).

${ }^{9}$ Ardian Adhi Chandra, "Kendala Yang Dihadapi Pelaku Industri Kreatif," 2016, https://m.detik.com.
} 
sifat penyelidikan yang sarat dengan nilai, mencari jawaban atas pertanyaan yang menekankan bagaimana pengalaman sosial diciptakan dan diberi makna. ${ }^{10}$ Pengumpulan data dilakukan melalui wawancara langsung dengan pihak pemerintah yang mana diwakili oleh Disperindag serta mendokumentasikan data-data yang dibutuhkan untuk menunjang keabsahan hasil penelitian.

\section{PEMBAHASAN}

\section{A. Usaha Pemerintah dalam Mengatasi Masalah Permodalan}

Usaha yang dilakukan oleh pemerintah Kota Cirebon (Disperindag) dalam mengembangkan ekonomi kreatif adalah dengan menjadi fasilitator dalam berbagai bidang termasuk bagian permodalan antara pelaku usaha dengan lembaga swasta atau pelaku usaha dengan lembaga pemerintah, salah satu usaha yang dilakukan oleh pemerintah dalam mengatasi permasalahan permodalan yang dihadapi oleh pelaku UKM ekonomi kreatif adalah sebagai berikut:

\section{Sosialisasi dukungan informasi penyediaan permodalan}

Pemerintah Kota Cirebon melalui Disperindag dalam tahun ini melakukan sedikitnya 2 kali sosialisasi permodalan terhadap para pelaku UKM termasuk UKM ekonomi kreatif, langkah ini dilakukan agar para pelaku UKM ekonomi kreatif mendapatkan akses permodalan untuk mengembangkan usahanya, dalam tahun ini besaran volume yang di targetkan dalam sosialisasi permodalan sebanyak 100 pelaku usaha sekota Cirebon. Sosialisasi yang dilakukan diantaranya adalah program KUR yang telah dicanangkan oleh pemerintah pusat, untuk sosialisasi program KUR ini dilaksanakan 1 kali dalam setahun. ${ }^{11}$ Modal yang telah diterima oleh UKM selanjutnya akan terus dievaluasi dan dimonitoring oleh Disperindag khususnya bidang UKM per triwulan untuk memastikan bahwa dana tersebut benar adanya digunakan untuk pengembangan atau kegiatan usaha.

\section{Sosialisasi program dari Kementrian}

Selain sosialisasi program pemerintah berupa KUR dan permodalan dari lembaga keuangan, Disperindag juga aktif dalam mensosialisasikan program dari kementrian salah satunya adalah program wirausaha pemula, dalam program ini tidak semua UKM akan mendapatkan bantuan, hal ini dikarenakan pihak dari kementrian akan memverifikasi kembali kriteria-kriteria yang sesuai dengan kementrian untuk mendapatkan bantuan permodalan.

\section{Pengecekan oleh Disperindag untuk memastikan kebenaran UKM}

Disperindag membuat tim kecil yang bertugas untuk memastikan keberadaan UKM-UKM di kota cirebon termasuk pelaku usaha kreatif, tujuan dari pengecekan kelapangan ini adalah untuk memastikan penyaluran bantuan pemerintah berupa permodalan sehingga

\footnotetext{
${ }^{10}$ Lincolin Denzin, Normank, Andyvonna, "Handbook of Qualitative Research 2nd Edition” (California, 2000).
}

32.

${ }^{11}$ Devi, “Usaha Pemerintah Kota Cirebon (DISPERINDAG) Dalam Menangani Masalah Permodalan” (2018). 
dana yang tersalurkan tepat sasaran dan dapat digunakan untuk pengembangan usaha kreatif kedepanya.

\section{B. Usaha Pemerintah Dalam Menangani Sumber Daya Manusia}

Usaha yang dilakukan oleh pemerintah Kota Cirebon (Disperindag) dalam mengembangkan ekonomi kreatif adalah dengan menjadi fasilitator dalam berbagai bidang termasuk bagian pengembangan kualitas SDM berupa pelatihan-pelatihan salah satu usaha yang dilakukan oleh pemerintah dalam mengatasi permasalahan Kualitas SDM yang dihadapi oleh pelaku UKM ekonomi kreatif adalah sebagai berikut:

\section{Penyelenggaraan pelatihan kewirausahaan}

Program unggulan dari Disperindag pada tahun ini salah satunya adalah program pengembangan kewirausahaan dan keunggulan kompetitif UKM melalui penyelenggaraan pelatihan kewirausahan bagi UKM, dalam program kerja tahun 2018 pelatihan kewirausahaan ini akan dilaksanakan sedikitnya sebanyak dua kali dalam satu tahun dengan jumlah peserta yang ikut mencapai 80 UKM yang tersebar di Kota Cirebon baik itu sektor kreatif maupun non kreatif. ${ }^{12}$

\section{Pelatihan UKM Go Online}

Pelatihan UKM go online ini merupakan program dari kementrian keminfo bekerja sama dengan kementrian koperasi dan UKM yang bertujuan untuk meningkatkan para pelaku usaha di Kota Cirebon agar lebih baik dalam melakukan usahanya, pelatihan seperti ini akan terus dilakukan kedepannya secara rutin melalui registrasi secara online. Pada tahun 2018 ini sebanyak 100 UKM di kota Cirebon telah mendapatkan pelatihan strategis dalam pemasaran online, pelatihan ini dilakukan selama 3 hari mulai dari tanggal 3 hingga tanggal 6 april 2018. ${ }^{13}$

\section{Pelatihan pengemasan}

Demi memajukan UKM dinas perindustrian dan perdagangan kota Cirebon mengadakan pelatihan dan pembinaan rutin kepada para pelaku usaha, kurang lebih sebanyak 50 pelaku usaha menjalani pembinaan agar menjadi pengusaha yang kreatif dan mandiri, pelatihan dan pembinaan tersebut meliputi packaging produk, penguatan mutu, hingga cara pemasaran. Disperindagpun dalam melakukan pelatihan dan pembinaan ini biasanya mendatangkan tenaga berpengalaman dibidangnya agar para pelaku UKM ini termotivasi dan mengeluarkan ide-ide kreatif dalam pengembangan usahanya. Setelah pelatihan dan pembinaan yang rutin dilakukan oleh Disperindag diperlukan juga motivasi dan pengetahuan yang lebih luas agar UKM lebih maju lagi,

${ }^{12}$ Devi, “Program Kegiatan Dinas Perdagangan, Koprasi Dan Usaha Kecil Menengah Kota Cirebon 2017” (Cirebon, 2017).

${ }^{13}$ Ma'ruf, "Untuk Ketiga Kalinya Pelaku Umkm Di Kota Cirebon Dapatkan Pelatihan Kewirausahaan Berbasis Online," 2018, http://dkis.cirebonkota.go.id. 
pelaku UKM yang dibina serta diberikan pelatihan bukan hanya pelaku dibidang kuliner saja namun juga pelaku dibidang souvenir, kerajinan tangan dan lainnya. ${ }^{14}$

\section{Pelatihan perpajakan}

Pengembangan kualitas sumberdaya manusia yang dilakukan oleh Disperindag bukan sebatas pengembangan yang terkait kemampuan produksi namun lebih dari itu, Disperindag pun mengadakan pengembangan sumberdaya manusia agar mahir dalam administrasi, salah satu usaha yang dilakukan pemerintah contohnya adalah dengan mengadakan pelatihan perpajakan, yang telah dilaksanakan pada tahun ini, pelatihan perpajakan ini dilakukan agar para pelaku usaha tidak kesulitan ketika mengurus pembayaran pajak hal ini dikarenakan tidak semua pelaku UKM faham tentang cara mengurus perpajakan.

\section{Usaha Pemerintah dalam Memperluas Pangsa Pasar}

Disperindag Kota Cirebon dalam upaya memfasilitasi pasar para pelaku UKM khususnya pelaku ekonomi kreatif adalah dengan mencanangkan beberapa program seperti kerjasama dengan market place online, kerjasama dengan supermarket seperti transmart di Kota Cirebon dan mini market seperti indomart atau alfamart di Kota Cirebon selain kerjasama langsung Disperindag juga memiliki web khusus UKM dimana setiap pelaku UKM dapat mengakses dan mempromosikan produk-produknya, web ini sudah mendunia dan semua barang yang dihasilkan dari pelaku UKM dapat dipasarkan di web tersebut. ${ }^{15}$

\section{Peningkatan kemitraan bagi usaha kecil menengah dengan pihak swasta}

Pada program ini pemerintah Kota Cirebon yang dalam hal ini diwakili oleh Disperindag melakukan sosialisasi kemitraan antara UKM dengan ritel modern dan UKM dengan perbankan, dengan besaran volume 2 kali kegiatan dan 50 pelaku UKM ditahun ini. Program kemitraan UKM dengan ritel modern diharapkan dapat mengembangkan produk UKM di kota Cirebon khususnya dalam hal pemasaran/promosi produk UKM serta memberikan tempat pemasaran bagi pelaku UKM sehingga produknya mudah dikenali oleh masyarakat.

\section{Penyelenggaraan promosi produk UKM}

Indikator yang digunakan pada program ini adalah bagaimana terlaksananya kegiatan promosi produk UKM melalui pameran lokal atau regional. Untuk mempromosikan produk UKM asal kota Cirebon pemerintah melalui dinas perdagangan mengadakan kegiatan pameran produk UKM yang dilaksanakan sebanyak dua kali, pameran ini melibatkan pelaku UKM sedikitnya 10 UKM.

Promosi yang dilakukan oleh pemerintah kota Cirebon untuk lebih mengenalkan produk UKM pada wilayah yang lebih luas diantaranya adalah dengan kerjasama antara

\footnotetext{
${ }^{14}$ AbaoutCirebon.id, “Disperindag Kota Cirebon Dorong IKM Lebih Kreatif Dan Mandiri,” 2018, http://m.kumparan.com.

${ }^{15}$ Devi, “Usaha Pemerintah Kota Cirebon (DISPERINDAG) Dalam Menangani Masalah Pemasaran” (2018).
} 
Disperindag dengan kota lain, seperti halnya kerjasama dengan Kab. Indramayu, sebagai contoh untuk memeriahkan hari jadi Kab. Indramayu pemerintah kota Cirebon ikut meramaikan pameran-pameran yang diselenggarakan oleh Kab. Indramayu dengan membawa beberapa produk kreatif dari UKM untuk dipamerkan, selain itu juga Disperindag bekerjasama dengan dinas pariwisata, dimana produk UKM dapat dijual dan dipromosikan di tempat-tempat wisata yang berada di luar kota Cirebon. Potensi pemasaran yang lebih besar didapatkan dengan menjalin kerjasama dengang dinas pariwisata, perdagangan produk kreatif di Kota Cirebon akan memiliki hubungan kepariwisataan dimana sektor pariwisata selalu berjalan bersamaan dengan sektor perdagangan (kerajinan tangan, kuliner), dengan majunya sektor perdagangan khususnya produk para pelaku UKM kreatif yang berada di kota Cirebon bukan tidak mungkin selain akan menumbuhkan usaha jasa pariwisata seperti hotel resort dll, tapi juga akan melahirkan destinasi wisata baru. ${ }^{16}$

\section{Kerja sama dengan market place online}

Disperindag Kota Cirebon telah bekerjasama dengan market place (toko online untuk memasarkan dan menjual produk UKM kota Cirebon, kerjasama yang sudah berjalan sampai saat ini adalah dengan toko online seperti bli.bli, toko bagus dan yang paling terbaru saat ini adalah shopee. Pemerintah kota Cirebon sudah mengajak dan mendaftarkan produk dari UKM di market place tersebut, khusus di kota Cirebon sendiri sudah banyak pelaku UKM yang go online bahkan informasi yang terbaru dari Disperindag dengan adanya UKM go online omset penjualan produk UKM kota Cirebon sudah mulai meningkat dari tahun-tahun sebelumnya. ${ }^{17}$

Kerjasama ini merupakan turunan dari pemerintah pusat dimana kementrian perdagangan membuat plafon untuk mewadahi UKM, untuk hal ini kementrian perdagangan terus bekoordinasi dengan toko online (market place) seperti Idea, tokopedia dll. Kementrian perdagangan Enggartiasto Lukita mengungkapkan masih banyak pelaku UKM di daerahdaerah yang belum faham tentang pemasaran produk menggunakan toko online oleh karena itu pemerintah pusat akan meminta seluruh pemerintah daerah untuk mendaftarkan produk yang dihasilkan oleh daerahnya masaing- masing, yang kemudian semua produk yang telah didaftarkan akan disaring dan diklasifikasikan, apakah termasuk mikro, menengah atau kecil. ${ }^{18}$

\section{Kerjasama dengan supermarket dan mini market}

Kerjasama yang dilakukan pihak Disperindag bukan sebatas market place semata namun lebih dari itu pihak Disperindag juga melakukan kerjasama dengan supermarket besar di Kota Cirebon, sebagai contoh adalah kerjasama dengan Transmart di kota Cirebon, serta

\footnotetext{
${ }^{16}$ Mustofa, “Potensi Pariwisata Dan Perdagangan Kota Cirebon,” 2017, http://disporabudpar.kotacirebon.go.id.

17 Devi, “Program Pemerintah Kota Cirebon (DISPERINDAG) Dalam Menangani Masalah Pemasaran” (2018).

${ }^{18}$ Lidya Julita, “Gabung Dilapak Baru Untuk IKM Dan UKM Jualan Online, Apa Syaratnya?" (Cirebon, February 2018), http://economy.okezone.com.
} 
beberapa mini market di Kota Cirebon, kerjasama telah dilakukan dengan supermarket besar dalam hal ini transmart, dimana pelaku UKM dapat memasarkan produk unggulannya di supermarket tersebut, walaupun ada beberapa keluhan dari pelaku UKM tentang lamanya waktu pembayaran serta prosedur pembayaran yang cukup rumit untuk setiap jenis barang terutama karena pelaku UKM masih dalam skala kecil.

Pemasaran yang dilakukan di transmart sebenarnya akan lebih berpotensi menarik pangsa pasar menengah keatas jika jumlah produk yang masuk lebih banyak dan lebih variatif, butuh konsistensi pemasaran di transmart tersebut untuk lebih mengenalkan produk UKM pada masyarakt luas. Selain di transmart produk para UKM pula sudah mengisi beberapa mini market seperti indomart yang berada di Kota Cirebon.

\section{Penyediaan web UKM}

Disperindag mempunyai web UKM dimana web tersebut berisikan data tentang UKM, dari data tersebut Disperindag dapat memantau perkembangan para pelaku UKM, di web tersebut memuat foto produk, contact person penjual hingga spesifikasi produk, sehingga setiap masyarakat yang ingin membeli produk UKM tersebut dapat menghubungi langsung contact person penjual, setiap pelaku UKM dapat menggunakan web tersebut tanpa terkecuali karena pemerintah sudah berkomitmen akan memfasilitasi para pelaku UKM dalam mengembangkan usahanya salah satunya dengan memasarkan produk melalui website UKM yang telah disediakan, namun web tersebut bukan merupakan market place seperti halnya bli bli, atau buka lapak yang mana sebagai market place, web yang dibuat oleh pemerintah ini hanya sebagai sarana untuk memasarkan produk sehingga pemerintah hanya sebagai penyedia sarana bukan sebagai penjual.

\section{Tinjauan Ekonomi Islam terhadap Model Pengembangan Ekonomi Kreatif di Kota Cirebon}

Umar Chapra mendefinisikan ekonomi islam sebagai suatu upaya yang dilakukan untuk mensejahterakan masyarakat melalui distribusi sumberdaya yang terbatas, mengatur manusia mengelola sumberdaya dengan koridor yang telah ditentukan oleh Islam. ${ }^{19}$

\section{Pengembangan permodalan}

Modal dalam konsep ekonomi islam dapat berarti $R a^{\prime}$ sul-maal yang berarti semua harta yang bernilai dalam pandangan syar'i yang aktivitas manusia ikut berperan serta dalam usaha produksinya dengan tujuan pengembangan. $R a^{\prime}$ sul maal tidak sebatas harta-harta ribawi saja, tetapi juga meliputi semua jenis harta yang bernilai yang terakumulasi selama proses aktivitas perusahaan dan pengontrolan perkembangan pada periode-periode yang lain. ${ }^{20}$ Pentingnya modal dalam kehidupan manusia ditunjukan dalam Ali-Imran: 14 yang Artinya:

Dijadikan indah pada pandangan manusia kecintaan pada apa-apa yang diingini, yaitu wanita-wanita, anak-anak, harta yang banyak dari jenis emas, perak, kuda pilihan,

\footnotetext{
${ }^{19}$ Umer Chapra, Ekonomi Dan Tantangan Ekonomi, Islam Kontenporer (Surabaya: Risalah Gusti, 1999).215.

20 Elis Mediawati, Konsep Utang Dan Modal Dalam Islam (Bandung: UPI Pers, 2013).5.
} 
binatang ternak, sawah dan ladang. Itulah kesenangan hidup didunia dan disisi Allahlah tempat kembali yang baik (Al-Imran : 14).

Ayat diatas menjelaskan tentang macam-macam hal yang disenangi oleh setiap manusia dan hal tersebut merupakan modal kebahagiaan hidupnya. Bagi pelaku ekonomi kreatif modal bukan hanya sebatas keindahan namun modal merupakan langkah awal dalam mengoptimalkan sumberdaya yang telah Allah berikan. Pentingnya modal dalam sejarah Islam membuat seorang sahabat yakni Saidina Umar r.a selalu menyuruh umat Islam untuk lebih banyak mencari aset atau modal. ${ }^{21}$ Selain itu Dalam Q.S Al-Mulk: 15 telah dijelaskan yang artinya:

Dialah yang menyediakan bumi itu mudah bagimu, maka berjalanlah ke segala penjurunya dan makanlah sebagian dari rizkinya, dan hanya kepadanyalah kamu kembali" (Al-Mulk : 15).

Arti dari ayat al-Quran diatas menjelaskan bahwa modal diperoleh dengan bekerja, memanfaatkan sumberdaya yang telah Allah sediakan, dalam memperoleh permodalan para pelaku ekonomi industri kreatif mempunyai dua alternatif, alternatif yang pertama adalah dengan menggunakan sistem uang muka dimana para konsumen memberikan dana awal sebagai perjanjian transakaksi jual beli yang kemudian akan langsung dilunasi sisanya pada saat serah terima barang, hal ini merupakan salah satu jalan bagi para pelaku usaha kreatif untuk bisa menjalankan produksinya dengan modal awal yang diberikan oleh konsumen. Alternatif kedua memanfaatkan bantuan permodalan dari pemerintah, permodalah yang dimaksud adalah hibah bagi para pelaku usaha ekonomi kreatif yang diberikan oleh pemerintah pusat (kementrian) besaran yang di berikan kisaran lima belas juta pertahun atau lebih, bantuan ini diberikan kepada para pelaku usaha kraeatif yang telah memenuhi kriteriakriteria yang telah ditetapkan oleh kementrian, selain hibah dari pemerintah pusat bantuan permodalanpun diberikan oleh lembaga keuangan bank seperti halnya BRI dan bank lainya yang telah bekerjasama dengan pemerintah, bantuan permodalan yang di berikan berupa sistem pembiayaan.

\section{Pengembangan SDM}

Sumberdaya manusia adalah alat untuk memanfaatkan seluruh karunia Allah yang mampu menciptakan efisiensi, efektivitas dan produktivitas dalam memaksimalkan sumberdaya yang ada. Islam memberkati pekerjaan di dunia dengan menjadikan seluruh aktivitas manusia yang berada di dalam koridor islam dimasukan sebagai kategori ibadah, sebagaimana yang dijelaskan dalam Al-Qur'an surat At-Taubah: 105 yang Artinya:

Dan katakanlah: "bekerjalah kamu maka Allah dan Rasulnya serta orang-orang yang mukmin akan melihat pekerjaanmu itu dan kamu akan dikembalikan kepada Allah yang mengetahui akan yang ghaib dan yang nyata, lalu diberitahukannya kepada kamu apa yang telah kamu kerjakan (. At-Taubah :: 105)

\footnotetext{
${ }^{21}$ Muhamad Djafar, Etika Bisnis Dalam Islam (Malang: UIN Malang Pres, 2007).40.
} 
Ayat diatas menjelaskan kepada kaum beriman agar mengerjakan pekerjaan yang memiliki nilai baik itu dimata manusia maupun dimata Allah karena sesungguhnya setiap apaapa yang manusia kerjakan akan kembali kepada manusia itu sendiri. Manusia memerlukan kemampuan yang optimal dalam mengelola sumberdaya yang telah Allah berikan dengan asas manfaat dan maslahat, hal ini merupakan anjuran untuk manusia yang hendak menggunakan kemampuan akalnya dalam menciptakan nilai ibadah, sebagaimana Islam menganjurkan kepada setiap manusia yang bekerja haruslah menggunakan akal dan kemampunya dengan optimal, mengeluarkan seluruh potensi yang dimiliki guna untuk menciptakan sesuatu yang lebih bermanfaat baik untuk diri sendiri maupun orang lain. Dari hal tersebut dapat dilihat bahwa ekonomi islam dljalankan dengan sangat teliti serta cara berfikir yang berpaku pada ajaran dan norma-norma islam yang bersumber dari Al-Quran dan Hadist. Sebagaimana yang telah di sebutkan dalam (Q.S Yunus : 100) yang artinya:

Dan tidak seorangpun yang beriman kecuali dengan izin Allah, dan Allah melimpahkan kemurkaan kepada orang yang tidak menggunakan akalnya".

Atas dasar tersebut pemerintah kota Cirebon telah melakukan kegiatan-kegiatan terkait pengembangan kemampuan sumberdaya manusia berupa pelatihan-pelatihan kepada para pelaku usaha baik pelaku usaha lama maupun pelaku usaha pemula.

\section{Pengembangan pemasaran}

Pemasaran dalam Islam merupakan sekumpulan aktivitas dalam menjalankan kegiatan bisnis, dimulai dari perencanaan, penciptaan, hingga penawaran kepada konsumen, berdasarkan ajaran islam yang prinsip dan dasar pemasarannya dilandaskan kepada hukum syariah, sehingga kegiatan seperti suap, manipulasi suplai, manipulasi penawaran dan permintaan, curang, dan kedzaliman merupakan tindakan yang harus dihindari dalam menjalankan aktivitas pemasaran. ${ }^{22}$ Pemasaran islam disebut pula sebagai spiritual marketing yakni upaya penerapan nilai-nilai spiritual dalam setiap strategi, program dan nilai yang diterapkan dalam pemasaran. Berikut konsep pemasaran yang di lakukan oleh UKM kreatif berdasarkan prinsip islam.

\section{a. Pragmatism and product}

Merupakan proses pemilihan produk jasa yang akan dijual haruslah sesuai dengan kebutuhan manusia. Dalam hal ini produk kreatif yang dijual di kota Cirebon meliputi produk primer,sekunder hingga tresier, seperti produk kuliner, fashion, dan kriya.

\section{b. Pertinence and promotion}

Yang berarti kegiatan promosi harus tepat dan sesuai dengan apa adanya, karena Islam melarang mempromosikan produk dan jasa dengan janji-janji yang berlebihan untuk menarik konsumen. Promosi yang dilakukan oleh pelaku UKM kreatif dan sesuai dengan aslinya hal ini telah diatur oleh pemerintah Kota Cirebon dalam menjajakan produk kreatif seperti halnya dalam web UKM. Untuk memastikan kebenaran UKM dan produk yang dihasilkan, pemerintah kota cirebon (Disperindag) melalui tim khusus melakukan

\footnotetext{
${ }^{22}$ Anwar Fathoni, “Konsep Pemasaran Dalam Presfektif Hukum Islam,” Jurisdictie UPN 9 (2018): 136.
} 
survey terlebih dahulu terhadap pelaku UKM hal ini untuk meminimalisir UKM abal-abal yang dapat merugikan konsumen.

\section{c. Palliation and price}

Yang berarti memberikan harga yang dapat diterima oleh pasar, seperti Nabi Muhammad yang selalu menjual barang dagangannya dengan harga yang dapat diterima oleh pasar, beliau mendapatkan keuntungan sesuai dengan volume barang sehingga mampu masuk keseluruh segmen pasar. Harga yang diterapkan oleh para pelaku UKM kreatif bervariatif, sebagai contoh produk kriya cendramata plakat kaca bekas, dalam penentuan tarifnya disesuaikan dengan jumlah kaca yang digunakan serta kerumitan dalam mendesain bentuk plakat, harga batik disesuaikan dengan pembuatanya sehingga batik tulis lebih mahal dibandingkan dengan batik cetak.

\section{d. Peer suport and people}

Yakni menjaga hubungan dan kepuasan konsumen untuk menciptakan suasana yang nyaman dan terhindar dari konflik dengan konsumen Pemerintah Kota Cirebon senantiasa menjaga kepuasan para konsumen terhadap para pelaku UKM kreatif dengan cara memastikan produk yang dihasilkan sesuai dengan apa yang dijual, melakukan pembinaan dalam peningkatkan inovasi dan manfaat dari produk yang dihasilkan, transparansi kelebihan dan kekurangan produk yang ditawarkan kepada konsumen serta memberikan pelatihan pemasaran produk baik itu berupa kemampuan dalam berkomunikasi baik secara tulisan maupun tulisan.

\section{e. Pedagogy and physical environtmen}

Merupakan pembiasaan diri untuk transparan mengenai informasi sebuah produk dan jasa yang akan dijual kepada konsumen, seperti yang dilakuakan Nabi Muhammad yang menjaminkan dirinya atas apa yang beliau jual kepada konsumen Dalam memasarkan produk UKM kreatif khususnya secara online, setiap pelaku UKM menjabarkan produk dan jasa yang akan dijualnya dihalaman web yang telah disediakan oleh pemerintah, disertai nomor telepon yang bisa dihubungi.

\section{f. Persistence and process}

Adalah ketekunan dan proses yang harus dilakukan oleh para pelaku UKM serta pemerintah dalam memperbaiki produk-produk lokal. Produk-produk yang dihasilkan oleh para pelaku UKM yang terus berinovasi dan memperbarui produk yang telah ada (baik itu bentuk, kemasan dII) hingga menciptakan produk baru, hal ini dilakukan oleh pelaku usaha untuk terus menarik konsumen dan meningkatkan harga penjualan melalui pengembangan kreativitas.

\section{g. Patience and place}

Yakni kesabaran dalam berniaga serta terus berproses sebagaimana jalan yang telah Allah atur melalui usaha yang telah dilakukan seperti yang dicontohkan oleh Nabi Muhammad pemerintah memfasilitasi tempat bagi para pelaku UKM kreatif baik itu berupa supermarket maupun mini market (yang telah melakukan kerjasama dengan 
pemerintah kota Cirebon) dimana tempat tersebut banyak di kunjungi oleh masyarakat kelas mengengah hingga ke atas, proses penitipan barang/hasil industri kreatif ke supermarket memerlukan proses yang cukup panjang sehingga para pelaku harus menunggu hingga segala persyaratan terpenuhi, selain itu tempat-tempat pada acaraacara besar kota Cirebon dan lain lain.

\section{KESIMPULAN}

Usaha yang dilakukan oleh Pemerintah dalam menangani masalah permodalan yaitu dengan mengadakan kegiatan seperti: sosialisasi dukungan informasi penyediaan permodalan, sosialisasi program dari kementrian, pengecekan oleh Disperindag untuk memastikan kebenaran UKM.

Usaha pemerintah dalam menangani sumber daya manusia yaitu melalui kegiatan: Penyelenggaraan pelatihan kewirausahaan, Pelatihan UKM Go Online, pelatihan pengemasan dan pelatihan perpajakan

Usaha pemerintah dalam memperluas Pangsa Pasar yaitu melalui: Peningkatan kemitraan bagi usaha kecil menengah dengan pihak swasta, Penyelenggaraan promosi produk UKM, Kerja sama dengan market place online, Kerjasama dengan supermarket dan mini market dan Penyediaan web UKM.

Tinjauan ekonomi Islam terhadap model pengembangan eknomi kreatif di kota Cirebon; Dalam hal pelaksanaan kegiatan yang berhubungan dengan akses permodalan, sudah sesuai dengan prinsip ekonomi islam yaitu berupa penyaluran bantuan kapada pelaku UKM dari program hibah, serta memastikan bantuan tersebut tepat sasaran namun masih ada yang belum sesuai syariah yakni pinjaman atau pembiayaan dari bank yang menggunakan sistem bunga sedangkan dalam (Al-Mulk:15) mengandung makna dalam pengembangan modal harus di lakukan dengan cara syar'i. Dalam hal pelaksanaan program yang berkaitan dengan sumberdaya manusia, hal ini juga sudah sesuai dengan ekonomi Islam dimana perintah manusia bekerja haruslah menggunakan akal dan kemampuanya dengan optimal (Yunus: 100). Usaha ini telah di lakukan oleh Disperindag berupa pemberian pelatihanpelatihan dalam rangka meningkatkan Kualitas SDM. Dalam hal pelaksanaan program yang berhubungan dengan akses pemasaran sudah sesuai dengan pondasi ekonomi islam yakni Nubuwah (Kenabian) dimana kerjasama yang dilakukan oleh disperindag dengan pihak swasta dan pemerintah di landasi dengan keterbukaan informasi produk.

\section{DAFTAR PUSTAKA}

AbaoutCirebon.id. "Disperindag Kota Cirebon Dorong IKM Lebih Kreatif Dan Mandiri," 2018. http://m.kumparan.com.

Aprilyani, Jane. "SDM Topang Pertumbuhan Ekonomi Kreatif," 2018. https://www.kontan.go.id.

Arif. "Dongkrak Ekonomi Kreatif Putra Daerah Ini Inisiasi Gerakan Kemakmuran Cirebon," 
2017. http://www.tribunnews.com.

Chandra, Ardian Adhi. "Kendala Yang Dihadapi Pelaku Industri Kreatif," 2016. https://m.detik.com.

Chapra, Umer. Ekonomi Dan Tantangan Ekonomi, Islam Kontenporer. Surabaya: Risalah Gusti, 1999.

Denzin, Normank, Andyvonna, Lincolin. "Handbook of Qualitative Research 2nd Edition." California, 2000.

Devi. "Program Kegiatan Dinas Perdagangan, Koprasi Dan Usaha Kecil Menengah Kota Cirebon 2017." Cirebon, 2017.

- - . "Program Pemerintah Kota Cirebon (DISPERINDAG) Dalam Menangani Masalah Pemasaran." 2018.

- - . "Usaha Pemerintah Kota Cirebon (DISPERINDAG) Dalam Menangani Masalah Pemasaran." 2018.

- - . "Usaha Pemerintah Kota Cirebon (DISPERINDAG) Dalam Menangani Masalah Permodalan." 2018.

Djafar, Muhamad. Etika Bisnis Dalam Islam. Malang: UIN Malang Pres, 2007.

Fathoni, Anwar. "Konsep Pemasaran Dalam Presfektif Hukum Islam." Jurisdictie UPN 9 (2018): 136.

Julita, Lidya. "Gabung Dilapak Baru Untuk IKM Dan UKM Jualan Online, Apa Syaratnya?" Cirebon, February 2018. http://economy.okezone.com.

Larassaty, Ayu Lucy. "Kontribusi Sumberdaya Manusia Di Bidang Industri Kreatif." Bandung, 2016.

Ma'ruf. "Untuk Ketiga Kalinya Pelaku UKM Di Kota Cirebon Dapatkan Pelatihan Kewirausahaan Berbasis Online," 2018. http://dkis.cirebonkota.go.id.

Mediawati, Elis. Konsep Utang Dan Modal Dalam Islam. Bandung: UPI Pers, 2013.

Mustofa. "Potensi Pariwisata Dan Perdagangan Kota Cirebon," 2017. http://disporabudpar.kotacirebon.go.id.

Nadia, Citra. "Cirebon Kota Pertama Di Gelar Bisma Goes to Get Member," 2018. www.bekraf.go.id,.

Pangestu, Mari Lela. Kebangkitan Ekonomi Kreatif. Jakarta: Retas Bekraf, 2016.

Wartoyo. Pemetaan Ekonomi Kreatif Dalam Upaya Pengembangan Dan Peningkatan Ekonomi Kota Cirebon. Cirebon: IAIN Syekh Nurjati Cirebon, 2017.

Wawan. "SDM Jadi Kendala Utama Industri Kreatif," 2012. www.Kompas.com. 